\begin{tabular}{l|l} 
Variants & $\begin{array}{l}\text { Variants } \\
\text { The Journal of the European Society for Textual } \\
\text { Scholarship }\end{array}$
\end{tabular}

12-13 | 2016

Varia

\title{
Variations in Understanding Variants: (Hidden) Concepts of Text in German Critical Editions
}

\section{Rüdiger Nutt-Kofoth}

\section{(2) OpenEdition Journals}

Electronic version

URL: http://journals.openedition.org/variants/343

DOI: $10.4000 /$ variants.343

ISSN: 1879-6095

\section{Publisher}

European Society for Textual Scholarship

\section{Printed version}

Date of publication: 31 December 2016

Number of pages: 148-162

ISSN: 1573-3084

Electronic reference

Rüdiger Nutt-Kofoth, « Variations in Understanding Variants: (Hidden) Concepts of Text in German Critical Editions », Variants [Online], 12-13 | 2016, Online since 01 May 2017, connection on 19 April 2019. URL : http://journals.openedition.org/variants/343 ; DOI : 10.4000/variants.343 


\section{Variations in Understanding Variants}

\section{(Hidden) Concepts of Text in German Critical Editions}

Rüdiger Nutt-Kofoth

Abstract: German textual scholarship developed different models of genetic presentations. While each genetic model requires a special concept of text, this concept is not always obvious at first glance. This article examines for what reason, for example, editors omit remarking on the precise variation process in the manuscript, why (and how) they indicate the position of the variants on the manuscript, why they abstain from presenting a reading text but opt to present the textual genesis only, why they add facsimiles and transcriptions to the genetic and the reading text presentation, or why they provide only facsimiles and transcription, but no reading text. Keywords: Text, Scholarly editing, Methodology, Editorial traditions, Critical apparatus, Historicalcritical edition, Genetic edition, German literature.

The Ongoing DebATES about text- versus document-based editions, prominently represented for instance by Hans Walter Gabler or Peter Robinson, are based upon discussions on materiality and mediality that were held in literary studies in the last few decades (Gabler 2007 and 2010, Robinson 2013). ${ }^{1}$ There is no doubt that these discussions were intensified by the increasingly accelerated development of the digital medium. Especially for scholarly editors, the digital medium changed its character more and more from a tool preparing the print edition to the final editorial product itself. It is, therefore, no coincidence that the Arbeitsgemeinschaft für germanistische Edition (Association for the Editing of German Texts) held its conferences 2008 and 2010 on the subject of "materiality" and "mediality" respectively. Since textual scholars like Jerome McGann, Peter Shillingsburg, David Greetham, George Bornstein and others have shown that "text" and the editorial object in which that "text" appears have different characteristics (McGann 1991,

\footnotetext{
1 I am grateful to Helen Swetlik for her editorial improvements in this article.
} 
Shillingsburg 1996 and 2006, Greetham 1999, Bornstein 2001), the digital medium seems to force us to rethink the whole agenda of textuality even further. Hence, Wim Van Mierlo is right when he argues in a recent Variants article on "Textual Editing in the Time of the History of the Book": "New technological possibilities are creating new ways of understanding what text is". And he adds: "The most radical change, however, is coming from the digital humanities." But he also gives a subtle hint that scholarly editing did not begin with digital editions so that scholarly editors of digital editions should "respectfully [keep] an eye on the traditions that they inherited from printed scholarly editions" (Van Mierlo 2013, 137).

In this essay I would like to look more closely at German editions of modern authors and I hope to make clear that print editions are not merely the obsolete ancestors of digital editions; print editions already apply a variety of different concepts of text, albeit at times implicitly; nonetheless these concepts have far-reaching consequences for the appearance of text in the edition. Discussions about the characteristics of digital editions would do well therefore to keep in mind earlier debates about text and editing. The test that brings to the fore such different concepts of text is the manner in which an edition deals with variants. The difficulty is, however, that editors do not always justify their treatment of variants, and where they do connect their way of presenting variants with specific editorial concepts they do not usually have in mind all conceptions of text that we are interested in today. Hence, to gain an insight into those hidden or at least not always obvious concepts of text we should approach those ideas with a dual interest: firstly uncovering systematically the concepts of text represented by the editorial presentation of variants, and secondly considering those presentations and concepts in a historically appropriate manner.

To start almost at the very beginning, about 150 years ago Karl Goedeke's edition of Friedrich Schiller's Sämmtliche Schriften (1867-1876) called itself "historisch-kritisch" on its title page. If one wants to characterize this edition and its treatment of the variants as an example of many of the older, traditional scholarly editions one has to accept a superior category that can be called "immaterial, abstract text". That means that these editions are interested in a textual representation of the text of the transmitted documents but they do not deal with the specific nature or medium of documents 
(for instance as manuscript or printed volume) nor with the spatial dimension of the text on these documents, the characteristics of the handwriting, or the typeface. The notion of 'text' in such editions is comprehended in an abstract, immaterial and unmediated manner. In other words, in this understanding the characters of the writing system can be transformed without any loss from the author's handwriting or the types of the authorised print to the different types and layout of a printed scholarly edition. In respect of the variants it can be observed that they are represented hierarchically. The first level of this hierarchy is the edited text that means the readable, the base text of an edition which in most German editions represents an historical version emended from textual faults, not an eclectic ideal text constructed from the transmission. Linearity is its main characteristic, regardless of whether, for example, the underlying manuscripts are linear or not. Variants are not differentiated. The critical apparatus treats all corrections and revisions in manuscripts, and all variant readings from other authorized editions, equally by putting them in a lemmatized word list. This apparatus is subordinated to the edited base text, first by spatial means because it is positioned below or behind the base text, and second by hierarchic means because the variant's textual position is indicated by its inevitable relation to, and therefore dependence, on the base text. The consequence is that the user of the edition cannot understand the variants on their own but only in their reference to another element of the edition.

Goedeke's Schiller edition shows such an hierarchic order: it places the variants at a level subordinate to the base text. The variants therefore look like textual scraps. Still, Goedeke placed the variants near the base text, in footnotes at the bottom of the page, and thus they are not completely separated from the base text. To do justice to Goedeke, it has to be mentioned that he was aware of the problems of such an editorial representation, particularly in respect of manuscript variants. In volume 15(2), which contains Schiller's dramatic fragments (1876), Goedeke pointed to a problem that would be solved only a hundred years later:

Nur eine photographische Wiedergabe könnte einen Begriff gewähren, was dem Dichter während der Arbeit der Aufzeichnung bedürftig erschien. Aber auch nur in der Photographie würde die 
Art seines eigentlichen Schaffens deutlich werden. Dazu reichen gestrichne Lettern und Schriftsorten verschiedenster Art nicht aus. (Schiller 1875, vi; reprinted in Nutt-Kofoth 2005, 31)

[Only a photographic reproduction could convey an idea of what the poet deemed necessary to record as he was working. And only photography could give a distinct impression of the nature of his essential creation. Cancelled letters and all sorts of typefaces cannot serve this purpose.]

The system of sigla that Goedeke introduces to represent the author's working process is a minimal first step towards a spatial and genetic presentation (see Schiller 1876, 333).

The next step in the historical development of the editorial position of text and variants appears in the Weimar Goethe edition, the most voluminous edition of a German author to date (Goethe 1887-1919). Its edited text is based on another concept, namely on the author's last version, and the edition is organized by genre, whereas Goedeke's Schiller edition uses an early version as base text and is organized chronologically. These differences are methodologically important for the history of German editions; they indeed can be regarded as opposite editorial concepts striking for supremacy in the early history of German literary studies (see for instance Nutt-Kofoth 2006). But with regard to an interest in the textuality of the variants' presentation you see there is no conceptual difference between Goedeke's Schiller edition and the Weimar Goethe edition. Both represent the author's text as an immaterial, abstract text, and like the Schiller edition the Weimar Goethe edition classifies text and variants in two different levels, making the variants dependent on the base text. However, the Weimar Goethe edition makes the separation of these two levels more apparent. Base text and apparatus are not put in a visual relation, as happens in the Schiller edition, but are placed in different parts of the volume or sometimes even in different volumes. Although the apparatus of the Weimar Goethe edition is much more comprehensive and detailed than that in the Schiller edition, it is at the same time much more difficult for the users of the edition to bring text and variants together. Indeed the variants in the Weimar Goethe edition bear more intensively the character of textual scraps than in 
Goedeke's Schiller edition. However, we can also observe that the apparatus of the Weimar Goethe edition implies certain information about spatial references, like "Word B after Word A" or "Word $B$ above Word A". That said, this does not mean that the apparatus of the Weimar Goethe edition is really interested in the position of the variants on the manuscript. Actually, these spatial descriptions are nothing more than a workaround for genetic descriptions for which acceptable solutions did not exist at that time. All in all we have to recognize that those nineteenth-century editions of modern German authors understand text as an abstract matter that is unproblematically transferrable from one materialized appearance into another. Both of these appearances share the same general writing system; in other words, the edition is only interested in representing the abstract type and not the concrete token. In this context only the base text bears the character of text. The presentation of fragmented variants illustrates that the apparatus has not yet found its new genetic task: to represent the textual deviations not for reason of text constitution but for making visible the author's working process. The variants in the Schiller and Goethe editions look like non-functionalized archival fragments.

The next systematically important stage in handling variants did not arrive until the 1930s when Friedrich Beißner developed his "stepped" apparatus that allowed him to render complex alterations in the author's writing process. The form was first tested in his edition of the writings of Christoph Martin Wieland in 1938 and was then used in the Friedrich Hölderlin edition, which appeared from 1943 onwards (Beißner 1938, extracted in Nutt-Kofoth 2005, 142-46; Hölderlin 1943-1985). On the one hand, text and apparatus are still separate in the Hölderlin edition; Beißner consolidated this nineteenth-century practice because the text and apparatus are now regularly placed in different volumes. The result is that the status of the edited text as a representation of the work becomes more self-sufficient than in either the Schiller or the Goethe edition. The step-like apparatus however is better suited to designate complex alterations and revisions, and indicates the growing independence of such passages. For the first time we encounter a form that takes the textual character of variants seriously. For the user of the edition, this means that he or she is no longer confronted with fragmented deviations but can read the internal genetic relationship 
between variants as connected text, or to be more precise as, connected text passages. Due to the alphanumeric numbering the editor does not need verbal descriptions for genetic information anymore. Nevertheless Beißner sometimes uses such descriptions. giving the genetic information within a lemmatized presentation. This is no more than a relic of former editorial methods as found in the Weimar Goethe edition for example.

Beißner is not really interested in the spatial dimension of the manuscript text; we can go as far as to say that he is not interested in any material aspect of the manuscript at all. For that reason, he did not indicate which elements of the genetic variants the author crossed out in his manuscript, which he wrote repeatedly, which are substitutions and which are alternative readings. One can say that these omissions characterize Beißner's editorial concept as imprecise with regard to the manuscript record. Beißner, however, was not interested in details of genetics, but in the "id e a le Wachstum" ("ideal growth") of the author's work that he abstracted from the manuscript record (Beißner 1961, 260 and 1964b, 81, reprinted in Nutt-Kofoth 2005, 260). He aimed to produce "lesbare Varianten" ("readable variants"), an aim nobody had attempted before (Beißner 1964a). Beißner - so much is clear - thus still adheres to the editorial paradigm that understands text only in its immaterial, abstract form; he was not at all, or at least not systematically, interested in the material aspects of text. Despite giving a new status to variants as more autonomous, like the editors that went before him he still organized text and variants in a hierarchic manner.

Aiming to make the apparatus more readable, Beißner gave a new prominence to variants as text to be read. The result however was that this genetic system was not only an imprecise reflection of the manuscript record but also a genetically inadequate one, since the system was oriented towards the last genetic step that make all intermediate steps look like discontinued and immediately corrected text pieces. It was Hans Zeller who tried to remedy these deficiencies with his synoptic apparatus for the Conrad Ferdinand Meyer edition (Meyer 1958-1996; Zeller edited vols. 1-7 containing the poems of Meyer). Beißner and Zeller's models have been described many times, and many times they have been labelled controversial (see Nutt-Kofoth 2008), but this is not the focus of this article. With regard to textuality the differences between the model 
provided by Beißner and that by Zeller are in fact smaller than they appeared to earlier commentators. Both editions refer to the immaterial, abstract understanding of text; both separate the base text from the apparatus by placing them in different volumes (albeit that in the Meyer edition the apparatus volumes outnumber the base text volumes at about five to one). Zeller's edition again has two levels of presentation, but now - and that is the first remarkable point - the genetic presentation gains further independence from the base text: the synoptic system does not need the base text as a reference text since the synopsis allows for a complete representation of all genetic stages of the work. Nevertheless Zeller retained the traditional distinction between text and apparatus still placing them in separate volumes. The second point that is really new is the spatial orientation of the apparatus, reflecting the spatial aspect of record. Zeller indicates all variants with position markers that inform the user where a variant is located in the manuscript: above, below, in front of or behind another word or group of words, or in the margin at the top, the bottom, the lefthand or the right-hand side of a page. These markers are indicated in the synoptic genetic presentation by small letters in italics and diacritics. When Zeller presented his enriched genetic system for the first time in 1958 he justified his procedure with reference to the reader deciphering and reconstructing the textual layers in the manuscript. In Zeller's own words the procedure ensures clarity, so that "sich der Leser von der H[and]s[chrift] ein Bild machen kann. Mir wenigstens ist ein Bedürfnis, die gedruckte Wiedergabe in die H[and]s[chrift] zurückzuübersetzen" (Zeller 1958, 362; reprinted in Nutt-Kofoth 2005, 200) ("it is possible for the reader to get a sense of the manuscript. It is my desire at least to retranslate the printed representation into the manuscript"). At first Zeller had his detractors who believed that this aim was simply unachievable, but Zeller countered this criticism by concentrating on another effect of his method, i.e. by precisely marking, and distinguishing between, the record-related and interpretation-related results of the editorial process in his edition. Though referring to the interest in editorial textuality Zeller's earlier argument - as strange as the result seemed to be - is a stronger one, because it includes spatial elements of the text and thus tries to transcend the boundary of the immaterial, abstract text towards the unique concrete realized 
material text. However, Zeller's Meyer edition suggests that this transition to the material text happens within an editorial method that still employs abstract, immaterial means of text representation. As a result, the edition looks too much like a hybrid; it is likely for this reason that hardly any historical-critical edition picked up on this material-oriented aspect of Zeller's synoptic model even though with regard to its genetic base the model was to become very successful in the following decades.

Although the synoptic apparatus has the ability to make all genetic stages of a work readable without reference to a base text, it was an edition in the Beißnerian tradition that realized this idea of mixing text and apparatus or correctly said that presents the apparatus as text. The two volumes of dramatic fragments of the Schiller-Nationalausgabe (National Schiller Edition, 1943-), published in 1971 and 1982, no longer distinguished between text and apparatus but understood the variants as part of the base text itself. By incorporating the Beißnerian genetic steps directly in the edited base text Herbert Kraft's edition of Schiller's dramatic fragments crossed the boundary between text and apparatus but not that between abstract and material text. Although the edition is based on the theoretical idea of the "Räumlichkeit als ein Theorem der Fragmentedition" (Kraft 2001, 132) ("spatiality as a theorem of the fragment edition"), the editorial representation of that space - e.g. the manner in which Schiller divided the page into two columns - is not completely equivalent to the manuscript record itself (see also Kraft 1975). Kraft's editorial concept is founded on the idea of structural spatiality. In his opinion the edition has to distinguish between accidental and structural spatiality. Structural spatiality represents the author's conceptual use of the writing space on the page. But when the author uses another part of the page for his corrections or alterations, he does so only because that is where there was still some space left; the placing of these revisions is nothing more than accidental. Kraft is of the opinion that such accidental spatiality is not worth representing in the edition.

It must be pointed out, however, that Kraft's editorial concept of spatiality only refers to the editing of fragments. In his view a fragment cannot be divided in genetic stages because the fragment itself is a preliminary stage of the as-yet-to-be accomplished work and therefore it does not contain any preliminary stages in itself. 
Still, the implications for the editorial concept of text that flow from Kraft's editions of Schiller's dramatic fragments are significant, for even if only for fragmentary texts the editions signalled the end of the separation between text and variants as well as their presentation in hierarchic levels. Variants became part of the edition's base text itself. Concurrently a part of the material record - its spatiality - served as an argument for the textual presentation of the base text. That in itself was a further step towards a material understanding of text, or in the very least case a step beyond Zeller's position markers, when spatiality shifted from the apparatus to the text. Despite this shift, Kraft's textual concept was still primarily based on an immaterial, abstract understanding of text, as it was in all older editorial understandings of text. The materiality of the physical manuscript still remained editorially invisible.

This abstract notion of text also remained at the heart of another edition that broke ground for the conceptual transformation from variants to text: the edition of Georg Heym's poems, published in 1993, prepared by Günter Dammann, Gunter Martens and Karl Ludwig Schneider (Heym 1993). This edition had been originally planned as an apparatus volume for the Heym edition of the 1960s. Its text volumes appeared, but the intended apparatus volume was never realized. It was the extensive study of Heym's manuscripts that led the editors to new theoretical considerations. When in 1971, the same year that Kraft's first volume of Schiller's dramatic fragments came out, Gunter Martens published their findings, he introduced a new theoretical understanding of text with his theory of "Textdynamik" ("textual dynamic"). Its main idea is that "die über variante Stadien verlaufende Entwicklung eines Werkes" can be understood "als eine wichtige textspezifische Aussage, ja sogar als spezifische Qualität von Text schlechthin" (Martens 1971, 167) ("the variant stages in the development of the work" can be understood "as an important text-specific statement, even as a specific quality of text per se"). Consequently, the traditional apparatus was no longer simply a part, but the "Kernstuck" ("core") of the edition, with the base text being no more than a "Superadditum zur Variantendokumentation" (Martens 1971, 171) ("special addition to the documentation of variants"). This concept was realized in the Heym edition of 1993 where the synoptic apparatus - or rather the text in the form of a synoptic apparatus - is the only text given in 
the edition, which deliberately omitted a supplementary base text presentation. The edition abolished for good the hierarchical order of text and variants by giving the variants - now understood as a textual unity - independent status as appropriate and necessary to present the textual genesis. Unlike Kraft's edition of Schiller's dramatic fragments, the Heym edition amalgamates variants and text for all types of text, not just for fragments. But at last the Heym edition remains in the realm of the immaterial, abstract text.

In 1975, four years after Martens' presentation of his theory of "Textdynamik", the Frankfurt Hölderlin edition took the first step towards material textuality by integrating a synoptic genetic text and a reading text with manuscript facsimiles accompanied by spatially oriented transcriptions (Hölderlin 1975-2008). Although the concept of the Frankfurt Hölderlin edition represents heralds a turning point in the history of German editing, it is important to point out that the inclusion of facsimiles was not done for its own sake, i.e. the presentation of the author's text as writing performed in a concrete spatial form and with particular writing instruments and material. Instead, the facsimiles and transcriptions serve as a tool for the reader to check to a certain degree the editor's work (Hölderlin 1975-2008 and Hölderlin 1975, 18; see also Groddeck and Sattler 1977, 7). ${ }^{2}$ While this means that the reader can use the edition to explore the material aspects of Hölderlin's texts, the edition nevertheless remains wedded to disclosing the abstract, immaterial text in the synoptic and reading texts.

Not until the Kafka edition of Roland Reuß and Peter Staengle, which started publication in 1995, was the border with the material text finally crossed (Kafka 1995-). And it did it so categorically that - concerning the manuscripts - any opportunity to return to the immaterial text was curtailed by the editors. Reuß and Staengle's Kafka edition only presents facsimiles and spatial transcriptions with some material-based genetic indications. The two traditional main tasks of editing modern authors, the exhaustive representation of the textual genesis and the establishment of a reading text,

2 "Die Wiedergabe der problematischen Handschriften im Faksimile ermöglicht die Überprüfung des Wortlauts, der Textentstehung und des Textzusammenhangs" (Holderin 1975, 18) ("The representation of the problematic manuscripts by facsimiles allows the verification of the wording, the textual genesis and the textual connection"). 
are programmatically excluded from the edition. Reuß justifies the edition's approach by declaring that a draft is not a text because of the draft's non-linear character. Since the editorially constituted text can refer only to linguistic objects that are (or contain) a text, such as a fair copy or a first print edition, the editor cannot create a reading text from a draft but can only present facsimiles and transcriptions (Reuß 2005, 7). As a consequence of this concept of text an editor cannot constitute a reading text from a draft. The Kafka edition in other words takes the material manifestation of textuality in the archival record very seriously; the facsimile is thus the core of the edition, while the transcription serves as a tool to read the handwriting. The edition arranges these facsimiles and transcriptions in the order of the manuscripts' physical creation. In the case of the novel fragment "Der Process" ( "The Trial") for example the page-by-page representation of Kafka's copybooks and - for imitating the materiality of the copybooks each of which usually contains a single chapter - the separated bound and unnumbered editorial units show that Kafka neglected to sort the chapters (Kafka 1995- and 1997). Since the edition is essentially orientated towards an archival dimension of editing, its concept of textuality is accordingly material based, even if Reuß avoids the use of the term "text".

After this short overview of the changes in how German scholarly editions understand base text and textual variants, I want to focus briefly on a further aspect of textuality within the context of variants and textual genesis: the inclusion of an author's textual sources in the Marburg Georg Büchner edition (Büchner 2000-2013). Furthermore, the edition reproduces these sources in extenso and links those that Büchner adopted and integrated in his work for a second edited reading text, using typographical means to indicate the intensity of these adoptions (see Dedner 1997). This method crosses another boundary, viz. that between the author's text and the text of other authors. Although the Büchner edition is an author-centred edition, it brings not only the aspect of intertextuality to the fore but it makes it visible within the editorial text and not - as is usual - in the commentary. In treating source texts in this manner, the edition highlights the intertextual nature of the work. As the source text becomes part of the textual genesis, it expresses a kind of intertextual variance to the text. 
On balance, this brief review of textual peculiarities and differences in understanding text and variants in editions of German-speaking authors of the last 150 years should illustrate nothing more than a spectrum of textuality of which one element or another was taken as a basis for the respective editorial concept. This spectrum ranges across editions that impose an hierarchical order between text and variant to editions that bestow increasing independence to variants, which are considered to be text in their own right. The spectrum also ranges from editions that represent text immaterially and abstractly to editions that incorporate certain spatial representations in the edited text and to editions that achieve a full, spatially oriented and archivally constructed text that subordinate - or even eschew - the reading text altogether in favour of a representation of textual genesis or the manuscript record.

We have to remember, though, that all of these conceptual innovations to represent the textual record were developed for print editions. It is obvious that the recent turn towards digital scholarly editing, and the obvious advantages the digital medium offers for integrating complex textual and documentary manifestations in the edition, will drive further innovation. Some of the areas where we will expect interesting developments are in visualization as a way of accessing the editorial object and in the possibilities of usercontrolled management. What we will have to discuss however is which elements in a digital edition are truly conceptually new and which derive from print editions but can perhaps be more fruitfully implemented in digital editions. That means we should try to distinguish more strictly qualitative from quantitative improvements of the digital edition. Therefore the meaning of the terms "text" and "variant" and its application within different concepts of textuality could serve as a test case. Understanding editorial representations of variants helps us to understand editions conceptually, print-based and digital editions alike.

\section{Bibliography}

Beißner, Friedrich, ed. 1938. Neue Wieland-Handschriften. Berlin: Verlag der Akademie der Wissenschaften. 
—_. 1961. "Aus der Werkstatt der Stuttgarter Hölderlin-Ausgabe". In Friedrich Beißner, Hölderlin: Reden und Aufsätze. Weimar: Hermann Böhlaus Nachfolger, pp. 251-65.

——. 1964a. "Lesbare Varianten: Die Entstehung einiger Verse in Heines 'Atta Troll'”. In Hugo Moser, Rudolf Schützeichel and Karl Stackmann, eds. Festschrift Josef Quint anläßlich seines 65. Geburtstages überreicht. Bonn: Emil Semmel, pp. 15-23.

—_. 1964b. "Editionsmethoden der neueren deutschen Philologie". Zeitschrift für deutsche Philologie 83, pp. 72-95.

Bornstein, George. 2001. Material Modernism: The Politics of the Page. Cambridge: Cambridge University Press.

Büchner, Georg. 2000-2013. Sämtliche Werke und Schriften: Historisch-kritische Ausgabe mit Quellendokumentation und Kommentar (Marburger Ausgabe). 10 vols. Eds. Burghard Dedner and Thomas Michael Mayer. Darmstadt: Wissenschaftliche Buchgesellschaft. Dedner, Burghard. 1997. “Die Darstellung von Quellenabhängigkeiten anhand von Beispielen". editio, 11, pp. 97-115.

Gabler, Hans Walter. 2007. "The Primacy of the Document in Editing". Ecdotica, 4, pp. 197-207.

—_. 2010. "Theorizing the Digital Scholarly Edition". Literature Compass, 7, pp. 43-56.

Goethe, Johann Wolfgang. 1887-1919. Goethes Werke: Herausgegeben im Auftrage der Großherzogin Sophie von Sachsen. 133 vols. in 143. Weimar: Hermann Böhlau / Hermann Böhlaus Nachfolger. Greetham, D.C. 1999. Theories of the Text. Oxford, New York: Oxford University Press.

Groddeck, Wolfram and D. E. Sattler. 1977. “Frankfurter Hölderlin-Ausgabe: Vorläufiger Editionsbericht". Le pauvre Holterling, 2, pp. 5-19.

Heym, Georg. 1993. Gedichte 1910-1912: Historisch-kritische Ausgabe aller Texte in genetischer Darstellung. Eds. Günter Dammann, Gunter Martens and Karl Ludwig Schneider. 2 vols. Tübingen: Niemeyer.

Hölderlin, Friedrich. 1943-1985. Sämtliche Werke: Große Stuttgarter Ausgabe. Eds. Friedrich Beißner and Adolf Beck. 8 vols. in 15. Stuttgart: J.G. Cottasche Buchhandlung Nachfolger and W. Kohlhammer. 
. 1975-2008. Sämtliche Werke, "Frankfurter Ausgabe": Historischkritische Ausgabe. Ed. D. E. Sattler. Frankfurt am Main and Basel: Stroemfeld and Roter Stern.

— . 1975. Einleitung. Unnumbered vol. of Sämtliche Werke, "Frankfurter Ausgabe": Historisch-kritische Ausgabe. Ed. D. E. Sattler. Frankfurt am Main: Roter Stern.

Kafka, Franz. 1995-. Historisch-Kritische Ausgabe sämtlicher Handschriften, Drucke und Typoskripte. Eds. Roland Reuß and Peter Staengle. Basel and Frankfurt am Main: Stroemfeld.

—_. 1997. Der Process: Faksimile-Edition. Eds. Roland Reuß and Peter Staengle. Basel and Frankfurt am Main: Stroemfeld.

Kraft, Herbert. 1975. "Die Edition fragmentarischer Werke". Zeitschrift für Literaturwissenschaft und Linguistik, 5 (19-20), pp. 142-46.

- 2001. Editionsphilologie. $2^{\text {nd }}$ ed. Frankfurt am Main: Peter Lang, Martens, Gunter. 1971. “Textdynamik und Edition. Überlegungen zur Bedeutung und Darstellung variierender Textstufen". In Gunter Martens and Hans Zeller, eds. Texte und Varianten: Probleme ihrer Edition und Interpretation. München: C.H. Beck'sche Verlagsbuchhandlung, pp. 165-201.

McGann, Jerome J. 1991. The Textual Condition. Princeton, NJ: Princeton University Press.

Meyer, Conrad Ferdinand. 1958-1996. Sämtliche Werke: Historischkritische Ausgabe. Eds. Hans Zeller and Alfred Zäch. 15 vols. in 16. Bern: Benteli, 1958-1996.

Nutt-Kofoth, Rüdiger, ed. 2005. Dokumente zur Geschichte der neugermanistischen Edition. Bausteine zur Geschichte der Edition 1. Tübingen: Niemeyer.

—_. 2006. "Two Paradigms in $19^{\text {th }}$ Century German Editing. Goedeke's Schiller Edition and the Weimar Goethe Edition as Different Steps towards a Particular Concept of Editing Modern Authors". In Luigi Giuliani et al. (eds.), Texts in Multiple Versions / Histories of Editions. Special issue of Variants, 5, pp. 315-30.

—_. 2008. "The Beißnerian Mode, the Zellerian Mode, and the Canonical Way of Modern Editing: Upheavals and Deviations in German Editorial Methodology - and its Historiography". In Hans Walter Gabler, Peter Robinson and Paulius V. Subačius (eds.), Textual Scholarship and the Canon. Special issue of Variants, 7, pp. 95-106. 
Robinson, Peter. 2013. "Towards a Theory of Digital Editions". Variants, 10, pp. 105-131.

Schiller, Friedrich. 1867-1876. Schillers Sämmtliche Schriften: Historisch-kritische Ausgabe. Eds. A. Ellissen, R. Köhler, W. Müldener, H. Oesterley, H. Sauppe and W. Vollmer. 15 vols. in 16. Stuttgart: Verlag der J.G. Cotta'schen Buchhandlung.

—. 1876. Nachlaß (Demetrius). Ed. Karl Goedeke. Vol. 15(2) of Sämmtliche Schriften: Historisch-kritische Ausgabe. Eds. A. Ellissen, R. Köhler, W. Müldener, H. Oesterley, H. Sauppe and W. Vollmer. Stuttgart: Verlag der J.G. Cotta'schen Buchhandlung, 1876.

—_. 1943-. Schillers Werke: Nationalausgabe. 43 vols. in 55. Weimar: Verlag Hermann Böhlaus Nachfolger.

— - 1971. Demetrius. Ed. Herbert Kraft. Vol. 11 of Schillers Werke: Nationalausgabe. 43 vols. in 55. Weimar: Verlag Hermann Böhlaus Nachfolger.

—_. 1982. Dramatische Fragmente. Eds. Herbert Krat, Klaus Harro Hilzinger and Karl-Heinz Hucke. Vol. 12 of Schillers Werke: Nationalausgabe. 43 vols. in 55. Weimar: Verlag Hermann Böhlaus Nachfolger.

Shillingsburg, Peter L. 1996. Scholarly Editing in the Computer Age: Theory and Practice. $3^{\text {rd }}$ ed. Ann Arbor: University of Michigan Press.

- 2006. From Gutenberg to Google: Electronic Representations of Literary Texts. Cambridge: Cambridge University Press.

Van Mierlo, Wim. 2013. "Reflections on Textual Editing in the Time of the History of the Book". Variants 10, pp. 133-61.

Zeller, Hans. 1958. "Zur gegenwärtigen Aufgabe der Editionstechnik: Ein Versuch, komplizierte Handschriften darzustellen". Euphorion, 52, pp. 356-77. 